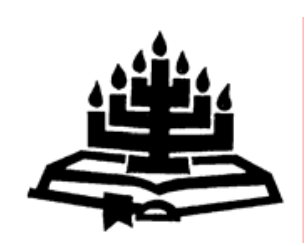

\title{
Occultism in an African context: a case for the Vhavenda-speaking people of the Limpopo Province
}

\author{
T.D. Mashau \\ School for Ecclesiastical Sciences \\ Potchefstroom Campus \\ North-West University \\ POTCHEFSTROOM \\ E-mail: Derrick.Mashau@nwu.ac.za
}

\begin{abstract}
Occultism in an African context: a case for the Vhavendaspeaking people of the Limpopo Province

Occultism in Africa is as old as the primal religion itself, or what came to be known as African Traditional Religion (ATR) in modern times. It dates back to time immemorial. Occultism in Africa has taken various forms and has manifested in different ways over the ages, i.e. spiritism, divination, witchcraft and magic. The underlying premise of African occultism is the belief in a spiritual world with spiritual forces that have power to inflict harm on the living. In the traditional African worldview suffering of every sort - illness, barrenness, drought and death - is normally explained in personal terms: "there is always somebody". This "somebody" often belongs to the world of the occult: a "spirit" has brought pain to human beings and must therefore be repelled or accommodated. This is very common among the Vhavenda-speaking people of the Limpopo Province. This article seeks to investigate how occultism is practised among these people and to provide a reformed perspective as to how people who are suffering under demonic attacks can be helped. Contrary to other Christian traditions that see exorcism as the only way out, reformed theology suggests a missio-pastoral approach in dealing with the problem.
\end{abstract}




\section{Opsomming}

\section{Okkultisme in 'n Afrika konteks: 'n gevallestudie van die Vhavenda sprekendes van die Limpopo Provinsie}

Okkultisme in Afrika is so oud soos die oergeloof self, of dit wat bekend geword het as die Afrika Tradisionele Godsdiens (ATG). Dit dateer terug na die vroegste tye. Okkultisme in Afrika het oor die tyd verskeie vorms aangeneem en verskillend gemanifesteer, byvoorbeeld in spiritisme, waarsêery, heksery en towery. Die onderliggende uitgangspunt van Afrika-okkultisme is die geloof in 'n geestelike wêreld met geestelike magte wat die mag het om lewendes skade aan te doen. Volgens die tradisionele Afrika lewensbeskouing kan enige swaarkry - hetsy siekte, kinderloosheid, droogte of dood - verduidelik word in persoonlike terme: "daar is altyd iemand". Hierdie "iemand" behoort gewoonlik tot die wêreld van die okkulte: 'n "gees" het swaarkry oor die pad van mense gebring en moet daarom uitgedryf of geakkommodeer word. Hierdie siening is baie algemeen onder die Vhavenda-sprekende mense in die Limpopo Provinsie. Hierdie artikel poog om ondersoek in te stel hoe okkultisme onder hierdie mense beoefen word en om 'n gereformeerde perspektief te verskaf in hulpverlening aan diegene wat onder 'n demoniese aanslag ly. Anders as ander Christelike tradisies wat demoonuitdrywing as die enigste pad sien, stel die gereformeerde teologie 'n missio-pastorale benadering tot die probleem voor.

\section{Introduction}

The word occult stems from the Latin word ocultus, and it carries the idea of things hidden, secret and mysterious (McDowell \& Stewart, 1982:9; cf. De Bruyn, 1992:28). The term covers a wide range of practices including astrology, other forms of divination, spiritualism, magic, witchcraft, Satanism, and Hindu/occult ancient wisdom groups such as ECKANKAR, Theosophy, Rosicrucianism, UFOcults, self-styled prophets, and the New Age movement (Gruss, 1994:168). Occultism therefore has to do with any form of practice in the life of human beings that acknowledges the presence of demonic ${ }^{1}$ powers that are hidden behind activities such as divination,

1 The word demon is a derivative of the Greek word daimoon or daimonion, meaning "devilish" in the Old Testament and in the New Testament "evil spirit" (messenger of Satan), except in Acts 17:18 where the word is used for a heathen god of the lower order. 
spiritism, magic and idolatry. ${ }^{2}$ Occultism in the African context has to do with the practice of tapping vital forces in the cosmos to influence human life favourably or unfavourably with the help of divination, witchcraft and magic. The occult phenomena are therefore phenomena relating to supernatural agencies, their effects, and knowledge of them. Those who engage in occultic practices are in most cases possessed and influenced by demonic powers or forces.

Occultism poses a serious problem to Christianity today (Bosch, 1987). This phenomenon is as old as the primal religion itself, or what came to be known as African Traditional Religion (ATR) in modern times. It dates back to time immemorial. Occultism in an African context has taken various forms and has manifested in different ways over the ages, i.e. spiritism, divination, witchcraft and magic. The underlying premise of African occultism is the belief in a spiritual world with spiritual forces that have the power to inflict harm among the living. In the traditional African worldview suffering of every sort - illness, barrenness, drought and death - is normally explained in personal terms: "there is always somebody". This somebody often belongs to the world of the occult: a spirit has brought pain to human beings and must therefore be repelled or accommodated. This is common among the Vhavenda-speaking people. It is therefore the objective of this article to investigate occultism in an African context by using the Vhavenda-speaking people of South Africa as a case study. An investigation of the worldview of the Vhavenda-speaking people suggests that occultism is a serious problem facing the church in the 21st century. The majority of mainline churches among the Vhavenda-speaking people have lost members to neo-Pentecostal and charismatic ministries who exercise exorcism as a result of the influence and manifestations of demonic powers in this region. This article seeks to go further than just investigating the reality of occultism among the Vhavenda-speaking people, by providing a reformed model for helping people who are practising occultism and those who are suffering as a result of demon possession and influence in their lives.

Vergeer (2002) and Viljoen (2006) have made efforts to provide a reformed model for dealing with demonic powers and its manifes-

2 Idols are not only images that are created and worshipped by human beings as their god-substitute, but they also represent evil spirits, demonic powers that are hidden behind them. 
tations. Their research clearly reveals that occultism is a present reality both in Africa and in the West. Both Vergeer and Viljoen looked at the whole question of demon possession and exorcism from a New Testament perspective, and they reached the conclusion that exorcism was exercised by Christ in a special way, because He had the godly authority to deal with it. Christ drove out demons as a sign that He came to overcome the evil one and his demonic exploitations. Vergeer (2002) and Viljoen (2006) proposed a reformed paradigm of dealing with this problem from a pastoral perspective. Whilst there is a strong correlation between their studies and the current research, this study goes a step further by proposing a missio-pastoral approach. Vergeer (2002:391) alluded to the fact that there is a need for the ministry of reconciliation in the whole process of dealing with demon possession, and this statement perhaps comes close to the aim of the current research.

\section{The Vhavenda-speaking people}

The Vhavenda people belong to the Venda tribe, one of the African peoples of South Africa. They now occupy the territory of the Soutpansberg in the Limpopo Province of the Republic of South Africa (see Burnett-van Tonder, 1987:1; cf. Van Warmelo, 1935). The Vhavenda people are composed of different social groups in accordance with their sibs, mitupo. Typical examples are: VhaDau, Ndou, Vhatavhatsindi, VhaLaudzi, Vhanyai, VhaMbedzi, Makhwinde, Vhafamadi, Vhatwanamba, VhaKwevho. Every sib has one or more honorific phrases, zwikhodo, and a taboo, tshiila, associated with it. The lion is associated with VhaDau, the elephant is associated with Ndou, water is associated with Vhafamadi, and so on (Stayt, 1931:186, 189, 192).

However, the Vhavenda people is a composite people who speaks one language, Tshivenda. Their language has slight dialectic differences, i.e. Tshiilafuri, Tshironga, Tshiphani (which is considered as the standard form), Tshinia, Tshimbedzi, Tshitavhatsindi and Tshilembethu. This is due to the division into different sibs. Apart from the different sibs, the Venda language has had linguistic influences from the Shona (Vhakalanga), Tsonga (Shangaan) and Sotho (the Pedi) neighbours (see Stayt, 1931:9; cf. Burnett-van Tonder, 1987:3; De v. Minnaar, 1992:1).

Their demographic figures are best described by Van Warmelo (1989:5): 
A 'census' held in 1904 produced a total of c.120 000 persons. Stayt gives a 'rough estimate' of 150000 in 1931. The 1970 census gave 358000 for all Venda-speakers in the whole of South Africa.

Currently the Vhavenda people come to just over a million, the majority of which are still situated in the area that was previously known as Venda. The true origin of the Vhavenda people cannot easily be accurately determined. They are said to have emigrated from central Africa via the Shona (Karanga) area in Zimbabwe to the Soutpansberg area in the Northern Transvaal around the 16th or 17th centuries. Apparently they merged with the VhaLemba people. The VhaLemba people are said to be of semitic origin (see Burnettvan Tonder, 1987:2; cf. West, 1976:90; Spoelstra, 1999:100, Stayt, 1931:14).

\section{Occultism among the Vhavenda people}

Occultism among the Vhavenda-speaking people is not something of the past - it is a present reality. The practice of tapping vital forces in the cosmos to influence human life favourably or unfavourably with the help of divination, witchcraft and magic, is still very much prevalent among the Vhavenda people. During the nineties of the twentieth century a witch-hunt occurred during which the homes and properties of those accused of being witches were burnt down (De v. Minnaar et al., 1992). Some even lost their lives in the process. At that time the whole of Venda was rendered ungovernable by that turmoil. Sporadic incidents still occur. Cases of people who are accused of witchcraft are reported on a regular basis in the area occupied by the Vhavenda people. Charismatic churches and ministries, with evangelists and faith-healers who claim to possess the gift of healing and exorcism, are mushrooming at an accelerated pace. Some members of reformed churches leave the church due to this development. The occurrence of this phenomenon among the Vhavenda can be attributed to their conception of God and the world. The same can be said of other African peoples.

\subsection{The concept of God}

The belief in one god is the most common concept among African peoples. According to Idowu (1969:24), god is real to Africans, and that is why Africans call him by names that are descriptive both of his nature and of his attributes. The Vhavenda believe in a mysterious deity who is called Raluvhimba or Mwali. The name Mwali is 
related to the name of the god of the Shona people of Zimbabwe, Mwari. ${ }^{3}$ The Mwari referred to here is the "Mwari weMatonjeni" 4 and not "Mwari weDenga". The Mwari weMatonjeni has historical links with the Venda people. Accordingly, there are links with and a continuation of the historical past, because even before they migrated to the southern parts of Rhodesia and northern Transvaal, the Venda had been closely associated with the Mbire tribe and regularly sent delegations to the Matonjeni shrines (Daneel, 1970:44).

Creation is attributed to Mwari. He is said to be the god who lives somewhere in the heavens and he is connected to all astronomical and physical phenomena (Stayt, 1931:230). All the natural phenomena that affect the people as a whole are said to be his revelations. Mbiti (1969:84) states: "The Bavenda regard locust invasion, floods, and other calamities of nature as punishment from God when he is angry with their chief." A typical example of this is the severe drought of 1924. This drought was ascribed to the fact that Chief Mphephu had failed to send an offering to Mwali at Mubvumela in the Matopos near Bulawayo in Rhodesia in that year (Van Rooy, 1978:6).

It remains an established fact that the Vhavenda people used to visit the Matonjeni shrines, especially when they encountered calamities. Peura, the keeper at Matonjeni shrines, who was a muVenda, remarked that the Vhavenda people only run to the shrines when a severe drought has convinced them that Mwari is angry (Daneel, 1970:53; cf. Van Rooy, 1978:6). According to the Venda legends, the Mwali weMatonjeni is said to have visited Venda several times in different centers for different purposes. Schutte $(1978: 119,120)$ mentions Mudzivhadi (for agriculture), Makonde, Luvhimbi, Musekwa, Mudimel, and among others, the Tshivhula people (Schutte, 1978:119,120).

3 Mwari is said to be the god of fertility, mainly of crops and women. He has both male and female attributes, hence he is regarded as the raingiver. He is closely associated with the Mbire tribe within the Shona tradition. His shrines or ritual headquarters are situated at Matopo hills near Bulawayo, hence he is known as Mwari weMatonjeni (the god of the Matopo hills). One of the keepers who served at the Matonjeni shrines was a muVenda called Peura (Daneel, 1970:16, 44; cf. Schutte, 1978:109, 110).

4 The Venda equivalent of the name Matonjeni was Matongoni (Schutte, 1978:121). 


\subsection{The concept of life}

Africans view life in its totality. This is based on their view of the cosmos. The cosmos is seen as a hierarchy of powers, each with its own place in the totality and each mutually influencing each other. The result is that the totality is seen as a hierarchy of powers, with God as an inherent part of it and occupying the top position.

The ideas of limited cosmic good, the priority of human relations and the influence of the spirits and witchcraft in the hierarchy play a significant role. Salvation, blessedness and peace depends on whether man is integrated in this totality, and then in his right place, because a Venda person sees him-/herself as part of a greater totality in which everything has a fixed and inter-related place. Their day to day life is not compartmentalised, and therefore such things as religion becomes an integral part and pattern of life. This implies that the totality mentioned above comprises all things as we know them. The comprehensiveness of the Vhavenda traditional worldview is best summarised by the following words: "According to the premises on which it is based, it is a logically integrated whole" (Van Rooy, 1978:1; cf. De v. Minnaar et al., 1992:6).

\subsection{The belief in the spirit world}

The belief in the spirit world is a very integral part of the Vhavenda worldview. They believe in the world of the dead who, through their spirits, are in constant contact with the living. There are certain locations all over the Venda area that are known to be inhabited by the spirits. In actual fact, every chief has or had a forest or mountains in which the spirits of his ancestors are supposed to abide. Accordingly, many of these places are the actual burying places of the chiefs. West (1976:91; cf. Mashau, 2004:98) confirms this when saying: "Spirits of dead chiefs were believed to live in particular sacred groves; others in the mountains, in pools and in streams."

\subsection{Ancestor cult}

The Vhavenda people believe in ancestral spirits known as midzimu in the plural and mudzimu in the singular. The ancestor cult remains central to their belief, so that their relationship with their dead ancestors has much more meaning than their relationship with Raluvhimba (West, 1976:91; cf. De v. Minnaar et al., 1992:8).

Believers view the dead ancestors as the ones who bring benefits and misfortunes to their descendants. Accidents, illness, miscarriage, and so on are supposedly caused by the angry spirits of one's 
family or the dead ancestors. Should one incur misfortunes in his life, the Vhavenda people will basically say "midzimu $i$ a hana" meaning that "the ancestor spirits are not in agreement or are refusing" (Stayt, 1931:230). As a result, the Vhavenda people never doubted the existence of the spirits of their deceased. They believe the spirits to be nearby and interested in the daily activities of their descendants (De v. Minnaar et al., 1992:8).

The practice of the ancestral cult is also prevalent in other African tribes and peoples. It is embedded in the African people's belief in life after death. Burial and funeral rites serve, among other things, to send the departed in peace to the spirit world, and to express condolences to the bereaved. Various symbols speak of death such as stopping normal activities for a day or more, shaving the heads, wearing colours that symbolise bereavement (white, black, or red), or extinguishing the fires in the homestead. Some societies bury a few personal belongings with the dead, such as spears, cooking pots, ornaments, money, and clothes. There are no concrete or institutionalised concepts of any paradise or hell in the hereafter, or rewards and punishment (with a few vague exceptions). Life in the hereafter is more or less a carbon copy of the present. The departed retain their human characteristics and the living dead are still part of their earthly families to whom they appear in dreams, in waking, or through divination, particularly if there is a major family event. The next world is inhabited by spirits and located in thick forests, desert places, underground, or on mountains. African Religion sees the universe in two intertwined parts: the visible and the invisible (Mbiti, 1991:116, 122).

Occultism among the Vhavenda people and other African peoples, is embedded in the ancestral cult practice. Demonic powers seize the opportunity to invade those who participate in this practice. In the end, people who practice ancestral cult fear ancestors more than God. Demonic powers invade and inflict fear in their lives.

\subsection{Rituals conducted}

There are certain rituals for communicating with the ancestors. If an individual is offended by his ancestors and he wants to communicate with them, the makhadzi ${ }^{5}$ can perform the ritual of spitting

5 The makhadzi is the sister to the head of the lineage, and is entrusted with the task of the "priest" of officiating the service of offering to the ancestors, thevhula. In this regard the traditional beer, mufhoho, is offered to the ancestors. 
out water, "u phasa madi". She does so mentioning the name of the offending spirit, followed by the names of all ancestors and finish with the mention of the unknown, "... na vhoiwe ri sa ni di" for "... and you whom we do not know" (see Stayt, 1931:250; cf. West, 1976:91).

\subsection{Objects associated with rituals}

There are certain objects associated with rituals within the tradition of the Vhavenda people. A sacred bull known as makhulu, for grandfather, is regarded as the embodiment of all the ancestral spirits. On the other hand, a female black goat, also known as makhulu, is said to represent the ancestors of the mother's lineage. Other objects related to the rituals include river pebbles, spears, copper rings, and sacred stones, et cetera (Stayt, 1931:243; 245).

\subsection{The belief in witchcraft}

The Vhavenda people believe that no misfortune just occurs by itself. They express it by saying: "A hu na tshi no da nga tshothe" ("There is nothing that happens by chance"). Consequently, they believe that certain misfortunes are caused by witchcraft, vhuloi. This is the act through which the muloi is said to have bewitched somebody to become sick, miscarry, deform, die, and so on. The muloi is associated with black magic (see Stayt, 1931:264, 274; cf. Burnett-van Tonder, 1987:8; Van Rooy, 1978:15).

In a case where someone is very sick, the witchdoctor, ńanga, is consulted for divination in order to determine the cause of the sickness. He also identifies the actual spirit concerned and the best means of propitiation. The ńanga is the medicine-man, who is more in line with practitioners, general or specialised (see Stayt, 1931:249; cf. De v. Minnaar et al., 1992:8). In case a person is believed to have been bewitched by a muloi, a diviner, mungome, is consulted. He specialises in detecting the muloi through his magical dice when he divines. The mungome would therefore be consulted when the family members would like to know the person who caused the death of their beloved one (Burnett-van Tonder, 1987:21).

The belief in witchcraft is prevalent in almost every African tribe and people. It is embedded in their acknowledgement of a mystical power created by God. People can use this power for good ends. These include the treatment of the sick, divination, exorcism of unwanted spirits, looking for a life partner, searching for success in 
undertakings like travelling, sports, examinations, election to a political position, et cetera. It is used for protection from misfortunes and theft of property, in predicting where to find lost articles, and foretelling the outcome of an undertaking. However, some people secretly also use the same power for evil magic, sorcery, and witchcraft. When things go wrong, such as sickness, childlessness in marriage, misfortune, accidents or failure in an undertaking, people attribute that to the evil use of this power. The belief in and practice of magic and witchcraft causes much fear, which in turn leads to accusations, quarrels, fights, and counter-measures in families and communities. However, people cherish the positive use of this mystical power in regulating ethical relations and in supplying answers to questions about luck, sicknesses and misfortunes (Mbiti, 1991:42).

\section{Forms of African occultism among the Vhavenda people}

Occultism among the Vhavenda people includes such activities as divination, necromancy, astrology, hypnotism, fortune-telling, magic, et cetera. The same applies to other African ethnic groups. African forms of occultism take the categories of divination, spiritism, magic (witchcraft) and idolatry.

\section{1 Divination}

Divination has to do with the foretelling of the future through magical acts. It is not only a means of discovering things to come, but is also used to uncover past secrets, and to smell out witches and sorcerers. Diviners among the Vhavenda people are said to have received their gift from their ancestors. As a result the diviner slaughters a goat or sheep for the ancestors from time to time in appreciation of what they have been given, and also to ensure that the ancestors do not take the gift back or stop giving them new revelations. Men consult diviners on many occasions, and they are among the most popular and busy figures in the religious life of Africans. This practice is still very much prevalent among the Vhavenda people, as it is among other African peoples. This practice is embedded in the spirit beliefs, because the assumption that there will be a sign showing truth or falsehood, guilt or innocence, implies the belief in a conscious, deliberate, honest, intelligent will-power that can and will change the objects or substances used so as to represent the truth or to express the will of the deity (Knappert, 1995:71). 


\subsection{Spiritism}

In the ancestral cult, Africans consult the spirits of the dead to ask certain favours in life. Spirit possession (malombo) among the Vhavenda people is common practise. This cult can be described as follows: The spirit of a departed ancestor is believed to occasionally make ill one of his/her descendants. The divining dice, when consulted, say the illness is due to malombo. This means that the spirit wishes to take possession of the patient. The treatment of such a person consists of singing by the bedside of the patient to the accompaniment of rattles (tshele), until the patient sits up and commences swaying his or her body round and round and nodding his or her head with ever-increasing violence. Then the patient suddenly falls straight forward and remains stiff and unconscious for quite a while. It is said mudzimu wo wa, the spirit has fallen, or has taken possession (Van Rooy, 1971:70). The spirit possession phenomenon is also prevalent among other African peoples and it is a clear manifestation that people are under the control of demonic powers (see Burnett, 2000:157).

\subsection{Magic}

Magic is the supra-natural way of influencing people and things negatively, with the help of evil powers (black magic - offensive magic) or positively, with the help of the gods (white magic). The African magician believes that there are vital forces, or spiritual powers, that he can tap. Black magic is much feared, and many charms are worn with the object of defeating black magic by the use of a stronger power. Babies are also loaded with bracelets and charms to protect them from evil influences and witchcraft. The Vhavenda children are loaded with these bracelets and charms during the ritual of $u$ thusa nwana ("for helping the child"). The child is not allowed to go out of the house for a period of at least three months until this ritual has been conducted. This is done for fear that the baby may contract diseases or be harmed by witchcraft (Mashau, 2004:96). 


\subsection{Witchcraft 6}

\subsection{Idolatry}

The Vhavenda people worship idols in the forms of sacred trees, goats, cows or flowers that are set apart for this purpose. These objects symbolise the reality behind them. Idolatry, therefore, should be mentioned as the fourth form of African occultism in the sense that idols are not only images of silver or gold, but represents evil spirits, demonic powers that are hidden behind them.

\section{Sacred places and sacred specialists}

As already noted, the spirits of dead chiefs were believed to live in particular sacred groves (zwifhoni); others in the mountains, in pools and in streams (see West, 1976:91). A typical example of the abovementioned is the Lake Fundudzi or Dzivha Fundudzi. Fundudzi is connected to the ancestor spirits of Netshiavha of the Tshiavha clan, who is the guardian of the Lake. It is also supposed to be inhabited by the spirits of other Vhatavhatsindi people (see Stayt, 1931:237; cf. West, 1976:91).

In addition, there are sacred specialits who perform certain rituals during the cultic and occultic practices. Parrinder (1954:100-109) mentions among others the following:

- Priests and priestesses: Women are more prominent than men in the conduct of religious affairs (makhadzi). These priests and priestesses are often set aside at birth or they may be called to the service of the god by being possessed by his/her spirit.

- Mediums: Connected closely with the priests are the mediums or devotees, who are possessed with the spirit of a god or ancestor. Such people, of whom probably the majority are women, may be attached to any temple or place where men come to consult an oracle. Like the ill-named "witch" of Endor, the medium proceeds, as in a spiritualistic séance, to gain control of a spirit and give messages from the spirit world. Through the mediation cult a person acting as a medium evokes and seeks to communicate with the evil spirits, or the spirits of the ancestors. This act is not only practiced by the Vhavenda people, but it is common among other African people (Burnet, 1988:190).

6 See the discussion on the belief in witchcraft above. 
- Diviners: They are specialists who seek to diagnose diseases, or discover the solution to problems by means of inspiration or manipulation of objects through various techniques (like the system of divination where they manipulate bones $-u$ tungula). During the process of divination, ancestors are expected to reveal to the diviner whatever the problem or sickness might be.

- Herbalists: They are men of trees in the sense that they possess the widest knowledge of the curative properties of herbs, plants, bark and roots. This is still very much part of the occultic practice among the Vhavenda people and other African peoples. Herbalists acknowledge that the knowledge they have of traditional medicines comes from their ancestors or a certain deity.

- Witchdoctor: His function is not to harm, but to heal and release the society from their pains, especially those who believe to be bewitched. They perform their duties as reactions against the evil activities of nocturnal witches. They also engage in purging the witches. Among the Vhavenda people, as is the case with other African peoples, people are trained to become witchdoctors. At the same time it is acknowledged that they receive this gift from their ancestors, and therefore the entire training is done in great acknowledgement of contributions from the side of the departed ancestors. The process of training is completed with a huge ceremony during which ancestors are appeased and thanked for the knowledge imparted to the graduates. Knowledge of different traditional medicines that cure different diseases is also said to be from the ancestors (cf. Parrinder, 1963:181).

\section{Manifestation of African occultism}

Given the context, one example that can be considered a manifestation of occultic powers is demon possession. While the manifestation is visible, the force behind it is not. According to McDowell and Stewart (1982:12) we can see the effects of a possession, but we cannot see the demon perpetrating the manifestation. These are some generally accepted criteria and symptoms of demonic possession:

- The exorcist discerns an evil presence or personality that is alien to the individual being exorcised.

- The person possessed speaks in voices distinctly other than his/ her own or in foreign languages unknown to the victim. 
- The person possessed utters blasphemies against God and everything sacred.

- The person possessed displays "impossible" physical contortions and undergoes convulsions. Some of those possessed by demons crawl like a snake.

- When a person is sick, it is also assumed that it is a sign pointing out that the spirit of his/her departed ancestor possesses the person. This is always a case where the kind of illness cannot be identified, even after the person has already consulted with the witchdoctor. The person will then be declared to have been spiritpossessed (see the discussion on spiritism above).

\section{Evaluation of occultism from a Biblical perspective}

A close reading of the Bible suggests that:

- Occultism is a sin against the first two of the Ten Commandments (Exod. 20:3-5).

- All forms of the occult - divination, necromancy, astrology, hypnotism, fortune-telling, magic, et cetera - are forbidden by God (Deut. 18:9-14; Jer. 10:2).

- The teachings of spiritism are doctrines of demons (1 Tim. 4:1).

- God has judgement over occultism (Exod. 22:18; Lev. 20:27; Rev. 9:20; 16:9). It greatly displeases and angers God.

\section{Towards a solution: a reformed perspective}

Occultism in an African context cannot just be dismissed as something superstitious. It is very real, as has been demonstrated by the case study of the Vhavenda-speaking people of the Limpopo Province. Members of the Christian church on African soil should be well-informed and equipped on how this phenomenon operates and how it can be combated. Whilst other Christian traditions see exorcism (Burnett, 2000:164) as the only way out, reformed theology suggests the following missionary and pastoral ways for people suffering from demonic attacks:

- The saving gospel of Christ should be proclaimed to these people (1 Cor. 1:22-23). True conversion and regeneration in Christ can set people free from their fear of demonic powers. The reconciliation ministry is central (Vergeer, 2002:391) to the whole ministry of dealing with people suffering as a result of being 
involved in occultic practices or people who are possessed by evil spirits or demons. There is no use for people to be prayed for and be set free for the time being, whilst they are not assisted to believe and trust in Jesus Christ as their personal Saviour and Lord. The message of the cross as the power of God to save and set people free from demonic powers, should remain at the core of dealing with the problem of occultism in the African context.

- Proper counselling in which a person deals with his/her fallen past, repent and confess his sins with the heart of seeking forgiveness in Christ can bring about true healing for those possessed by the evil spirits. A model provided by James 4 can serve as an example as to how people possessed by evil spirits can best be helped. The healing model of James 4:13-18 encourages the church to adopt a holistic approach in dealing with pain and suffering, including those who have been involved in occultic practices and are demon possessed. A person who has been involved in occultic practices needs to be open about his/her involvement. Church leaders should have ample time to listen to the stories of people who have been involved in occultic practices. The whole process of conducting proper counselling sets the scene for sincere prayer with the notion of openness about ones weakness and sins before God. It reminds both the counselor and the counselee to acknowledge their reliance upon Christ and the power of his resurrection, which gives us hope in dealing with suffering and affliction in this life.

- Those who seek repentance in Christ should be encouraged to totally break with occultic practices. This should be taken in a serious light because there are nominal Christians in Africa who still adhere to the veneration of the ancestors and also consult sangomas (witchdoctors) when confronted with life challenges like illness.

- All African Christians should be encouraged to engage in the nature of a Christian spiritual life (Eph. 6:10-20). They should engage in a spiritual warfare (Powlison, 1995) which also includes such things as prayer and reading of the Bible on a regular basis. This also includes a total break from the past life where a person lived under the control of sin. Christians in Africa should be encouraged to have a living fellowship with Christ, hence they will become victors over the evil one and his evil messengers. 


\section{List of references}

BOSCH, D.J. 1987. The problem of evil in Africa: a survey of African views on witchcraft and of the response of the Christian church. (In De Villiers, P.G.R. Like a roaring lion: essays on the Bible, the church and demonic powers. Pretoria: UNISA. p. 138-162.)

BURNETT, D. 1988. Unearthly powers: a Christian perspective on primal and folk religion. Eastbourne: MARC.

BURNETT, D. 2000. World of the spirits: a Christian perspective on traditional and folk religions. London: Monarch.

BURNETT-VAN TONDER, C. 1987. Sosio-etniese danse van die Venda-vrou. Kaapstad: HAUM.

DANEEL, M.L. 1970. The God of the Matopo hills. The Hague: Mouton.

DE BRUYN, P.J. 1992. The Ten Commandments. Midrand: Varia.

DE V. MINNAAR, A., OFFRINGA, D. \& PAYZE, C. 1992. To live in fear: witchburning and medicine murder in Venda. Pretoria: HSRC.

GRUSS, E.C. 1994. Cults and the occult. 3rd ed. New Jersey: P \& R Publishing.

IDOWU, E.B. 1969. God. (In Dickson, K.A. \& Ellingworth, P. Biblical revelation and African beliefs. Great Britain: Billing. p. 17-29.)

KNAPPERT, J. 1995. An encyclopedia of myth and legend: African mythology. Britain: Diamond.

MASHAU, T.D. 2004. The Reformed Churches in South Africa's missionary pilgrimage among the Vhavenda people at Siloam. Studia historiae ecclesiasticae, 30(1):90-107.

MBITI, J.S. 1969. African religions and philosophy. Washington: Praeger.

MBITI, J.S. 1991. Introduction to African religion. 2nd ed. Kampala: East African Educational Publishers.

MCDOWELL, J. \& STEWART, D. 1982. Understanding the occult: handbook of today's religions. California: Here's Life Publishers.

PARRINDER, E.G. 1954. African Traditional Religion. Cape Town: Hutchinson.

PARRINDER, E.G. 1963. Witchcraft: European and African. London: Faber \& Faber.

POWLISON, D. 1995. Power encounters: reclaiming spiritual warfare. Grand Rapids: Barker.

SCHUTTE, A.G. 1978. Mwali in Venda: some observations on the significance of the high god in Venda history. Journal of religion in Africa, 9(2):109-122.

SPOELSTRA, B. 1999. Sending vir kerk of koninkryk? Sendinggeskiedenis van die Gereformeerde Kerk van Suid-Afrika, 1869-1994. Potchefstroom: Potchefstroomse Teologiese Publikasies.

STAYT, H.A. 1931. The Bavenda. London: Oxford University Press.

VAN ROOY, J.A. 1971. Language and culture in the communication of the Christian message as illustrated by the Venda Bible. Potchefstroom: PU vir CHE. (Th.D. dissertation.)

VAN ROOY, J.A. 1978. The traditional worldview of black people in Southern Africa. Potchefstroom: IBC.

VAN WARMELO, N.J. 1935. A preliminary survey of the Bantu tribes of South Africa. Pretoria: Government Printer.

VAN WARMELO, N.J. 1989. Venda dictionary: Tshivenda - English. Pretoria: Government Printer.

VERGEER, W.C. 2002. Okkultiese binding en bevryding: 'n NuweTestamentiese perspektief. In die Skriflig, 36(3):369-395. 
VILJOEN, F.P. 2006. Jesus en demoonuitdrywing: 'n ondersoek na Jesus se hantering van demone volgens die Evangelis. In die Skriflig, 40(2):221246.

WEST. M. 1976. Abantu: an introduction to the black people of South Africa. Johannesburg: Struik.

\section{Key concepts:}

ancestral cult

demonology

occultism

spirit world

Kernbegrippe:

demonologie

geesteswêreld

okkultisme

voorvaderkultus 
